\title{
$X: 115113885-115117702$
}

National Cancer Institute

\section{Source}

National Cancer Institute. X: 115113885-115117702. NCI Thesaurus. Code C41670.

Physical location of AGT R2_Gene 